\title{
Perimolysis: case report
}

\author{
Perimólise: relato de caso clínico
}

\author{
Carolina Pratti DANIEL ${ }^{1}$ \\ Hérica Adad RICCl${ }^{2}$ \\ Eloísa Marcantonio BOECK² \\ Flavia Magnani BEVILACQUA ${ }^{3}$ \\ Jaqueline Braga Barbosa CERQUEIRA-LEITE²
}

\begin{abstract}
Perimolysis is a form of dental erosion, characterized by dental tissue demineralization without bacterial involvement. It can be of intrinsic or extrinsic origin. Extrinsic origin is considered when it is caused by excessive consumption of acid drinks and foods such as soft drinks, alcoholic beverages, acid fruit and prescription drugs for daily use. When caused by gastrointestinal disorders, such as those resulting from bulimia, anorexia nervosa and gastroesophageal reflux, it is considered of intrinsic origin. The acid action can cause erosion on palatal/lingual incisor surfaces, and occlusal and palatal/lingual posterior tooth surfaces causing pain (dental hyperesthesia). Treatment is often multidisciplinary, and the causes should be identified, eliminated or controlled. In dentistry, the approach must include preventive measures to reduce future risks, and restorative intervention using materials such as glass ionomer cement, resin composite, or endodontic and prosthetic rehabilitation in more complex cases. The aim of this study was to describe the restorative treatment in the case of a patient with this condition.
\end{abstract}

Indexing terms: Acidity. Dental enamel. Esthetics. Tooth erosion.

\section{RESUMO}

Perimólise é uma forma de erosão dentária, caracterizada pela desmineralização do tecido dental sem envolvimento bacteriano, de origem intrínseca ou extrínseca. É considerada de origem extrínseca quando causada pelo consumo excessivo de bebidas, alimentos e substâncias ácidas, como refrigerantes, bebidas alcoólicas, frutas ácidas e medicamentos de uso contínuo. Denomina-se intrínseca quando causada por distúrbios gastrintestinais como os que ocorrem como conseqüência da bulimia, da anorexia nervosa e do refluxo gastresofágico. A ação ácida pode causar erosão nas faces palatina/lingual dos incisivos e palatina/lingual e oclusal dos dentes posteriores levando a dor, ou seja, hiperestesia dental. O tratamento geralmente é multidisciplinar, devendo identificar e eliminar ou controlar as causas. A abordagem odontológica deve associar medidas preventivas para diminuir riscos futuros e intervenção restauradora utilizando materiais como cimento ionômero de vidro, resina composta ou até mesmo endodontia e reabilitação protética para casos mais complexos. Este trabalho teve como objetivo descrever o tratamento restaurador de um caso clínico de paciente com esta patologia.

Termos de indexação: Acidez. Esmalte dentário. Estética. Erosão dentária.

\section{INTRODUCTION}

Perimolysis is a form of tooth erosion, characterized by dental tissue demineralization without bacterial involvement; that is, wear or mineral loss from the tooth surface caused by chemical agents ${ }^{1-2}$.

Mineral loss (erosion) from the tooth surface may lead to painful conditions (dentin/tooth hyperesthesia), with esthetic and functional compromise, factors that lead to the patient going to the dentist ${ }^{1-4}$.

Areas of wear may be promoted by acid substances frequently coming into contact with the teeth.
These substances may be of intrinsic or extrinsic origin 1,2,4. Wear arising from extrinsic substances are very common nowadays, because of changes in the dietary habits of human beings, who now consume more products of industrial origin. In the majority of cases, these contain acid substances as preservatives that contribute to the appearance of perimolysis ${ }^{5-6}$.

Among the main factors related to the type of diet involved in the high rates of tooth erosion are the consumption of citrus fruits, habit to suck acid or sour candies, in addition to the ingestion and continuous use of some medications, such as Vitamin C and acid mouth washes ${ }^{7}$.

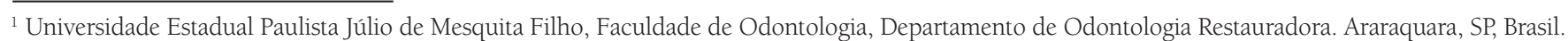

${ }^{2}$ Centro Universitário de Araraquara, Departamento de Clínica Infantil. Rua Carlos Gomes, 1338, Centro, 14801-340, Araraquara, SP, Brasil. Correspondência ára / Correspondence to: JBB CERQUEIRA-LEITE. E-mail: <hericaricci@yahoo.com.br>

${ }^{3}$ Universidade Paulista, Curso de Odontologia, Departamento de Dentística. Campinas, SP, Brasil.
} 
There is also the possibility of dental structure loss occurring due to parafunctional problems (bruxism) or occupational factors, such as exposure to industrial gases that contain hydrochloric or sulphuric acid, and acids used in galvanization, battery and ammunition manufacturing, and other industrial processes.

Among the intrinsic factors causing perimolysis, manifestations of bulimia are highly frequent. In the modern social context, it has been concluded that the majority of gastrointestinal dysfunctions affect persons who follow a pattern of beauty recommended by the media, in which, in the majority of cases, the obsessive ideal to have a lean body leads to psychosomatic disturbances, with physical consequences characterizing pathologies such as bulimia and anorexia nervosa ${ }^{8-10}$.

Bulimia is characterized by the ingestion of an excessive amount of food, with the term "bulimia" being derived from the Greek language, meaning "oxhunger" . The patient east compulsively, and with the intention to control weight, deliberately provokes vomiting. Whereas, anorexia nervosa is characterized by the patient's aversion to any type of food, and consequently does not eat.

Decalcification of the dental structure, characteristic of perimolysis, causes the formation of smooth lesions and pigmented stains with rounded margins in the teeth, which affect the palatal and incisal surfaces of the maxillary anterior teeth, shortening them. The lingual surfaces of the mandibular anterior teeth and the occlusal and lingual surfaces of posterior teeth may also be affected ${ }^{11-12}$.

The restorative dental treatment of patients who present perimolysis may be performed by means of direct resin composite or glass ionomer cement restorations; indirect restorations with laminated veneers, inlays, onlays or total crowns. As a result of the wear, endodontic treatment may be necessary, and if there is hypersensitivity, desensitizing therapy may be required. Associated with restorative dental treatment, it is necessary to apply preventive measures that allow a reduction in the risk of decalcification, and strengthen the remaining structure, in addition to acting in conjunction with a multidisciplinary team, constituted of the Dental Surgeon, doctors, nutritionists and psychologists ${ }^{12-14}$

The great challenge to the treatment of perimolysis, which frequently goes unnoticed by the dentist, appears to be making the correct diagnosis, Therefore, studies that offer professionals explanations about the main causes and forms of treatment, and the importance of the participation of a multidisciplinary in the treatment are extremely important.

\section{CLINICAL CASE}

The patient E.N.S., a 38-year-old woman, presented to the Dental Clinic of the Araraquara University Center, complaining of "tooth wear and sensitivity". Anamnesis and clinical exam were performed, and by means of the information obtained in the patients report that she had undergone psychiatric treatment for depression, and that she provoked vomiting daily after meals, associates with the dental characteristics (Figures 1, 2 and 3) of wear, dental perimolysis was diagnosed. With the information gathered and also observed by contact with the patient, the etiological agent of the perimolysis was found to be very suggestive of bulimia nervosa.

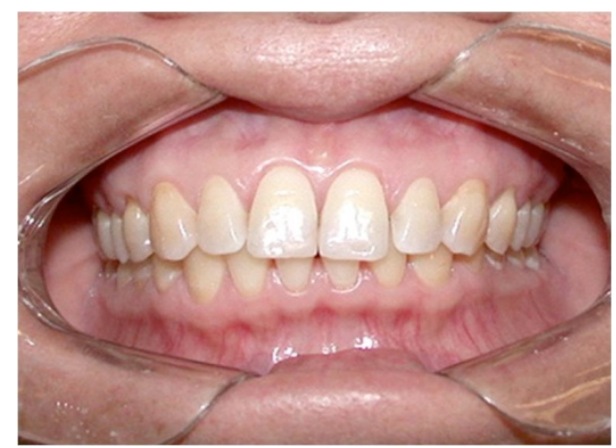

Figure 1. Initial clinical case.

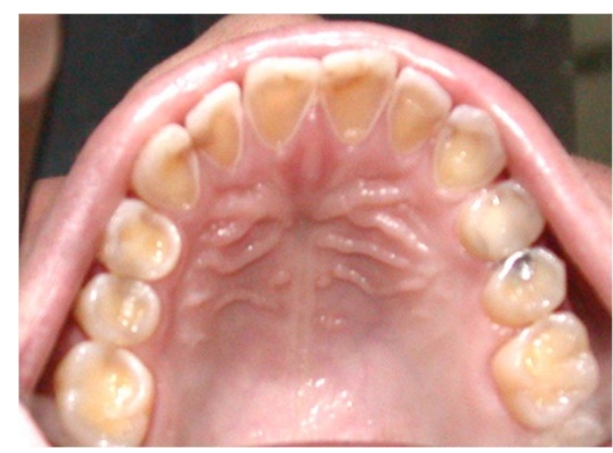

Figure 2. Aspect of erosion observed in the anterior teeth, with dentin exposure.

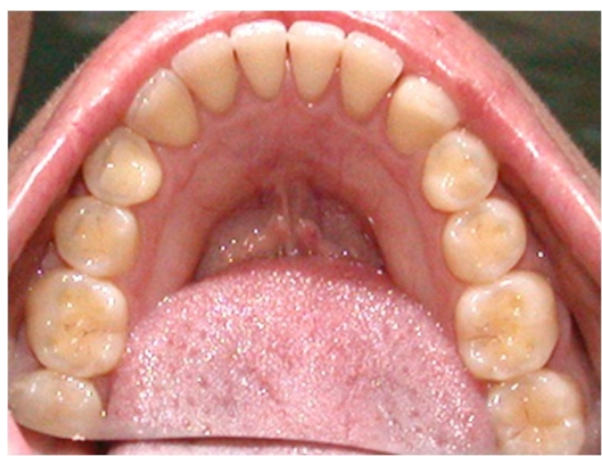

Figure 3. Aspect of erosion observed in the posterior teeth with loss of vertical dimension. 
From the intraoral exam it was found that the patient presented no soft tissue lesions, and in spite of the generalized wear of the tooth tissues, the patient was free of caries and periodontal disease. Dental wear was shown to be accentuated, involving the palatine surfaces of maxillary incisors, and occlusal surfaces of maxillary posterior teeth. The anterior teeth were significantly weakened by the degree of wear, and it was possible to visualize the proximity of the pulp tissue by the exposed palatine dentin. The maxillary left second molar presented a small amalgam restoration on the occlusal surface, of which the margins protruded due to the dental structure wear.

A treatment plan was prepared, including multidisciplinary action, and the patient was referred for verification of the condition of bulimia and adequate treatment. Thus psychotherapy was associated with preventive and direct restorative treatment with resin composite. This treatment was approved by the Research Ethics Committee of the Araraquara University center, protocol N. 756.

The treatment planned involved the establishment of preventive measures to prevent or control the risk of future dental wear, suited to the patient's needs, including the application of topical fluoride, prescription of daily mouth washes with fluoride (concentration of $0.05 \%$ ), and guidance with regard to diet (control of ingestion of acid substances) and oral hygiene. Restorative treatment was highly conservative; that is, without cavity preparation, avoiding wear of the teeth. The resin composite was bonded to the affected surfaces by means of an adhesive system, thereby restoring shape, function and esthetics to the teeth (figure 4).

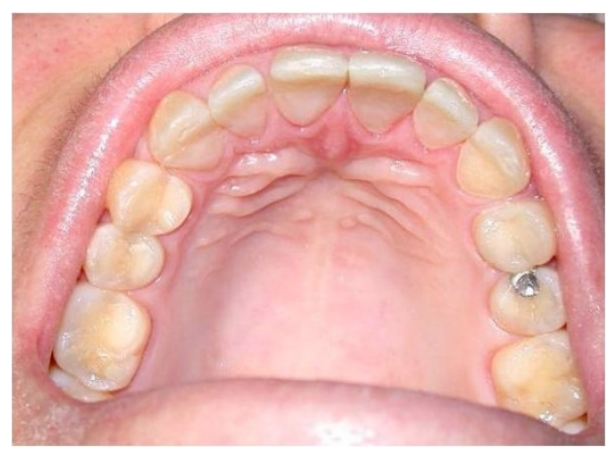

Figure 4. Finalized clinical case, with recovery of vertical dimension

Dental surgeons should also alert their patients about care taken with excessive tooth brushing after vomiting, guidance about diet, ingestion of acid beverages with the use of straws, guidance as regards performing mouth washes with alkaline solutions of bicarbonate of soda, and referral for medical and psychological treatment.

It is important to point out that dental treatment was performed only after obtaining the term of free and informed consent, duly signed, which had previously been analyzed and approved by the Research Ethics Committee of the Araraquara Dental School (Protocol N. 756).

\section{DISCUSSION}

The clinical case described presented accentuated alteration in the dental structures, enamel and dentin, compatible with the characteristics described in the literature ${ }^{3-4,12}$. As regards its etiology, perimolysis may be caused by acids of internal (intrinsic) or external (extrinsic) origin to the human body, without involving bacterial action ${ }^{1-2,4}$.

With regard to extrinsic causes, chronic alcoholism, abusive use of soft drinks and certain dietary habits ${ }^{5,7,15-16}$ were excluded as etiological factors related to this clinical case during careful anamnesis.

As far as intrinsic causes are concerned various authors ${ }^{1,3-4,6,8,11-14,17-18}$ have associated the presence of pathologies such as bulimia and anorexia nervosa, chronic refluxes and regurgitations of the acid content of the stomach (hydrochloric acid) due to gastroesophageal disturbances, pregnancy, psychosomatic disorders and hiatus hernias. In the present case, in spite of the initial complaint being tooth sensitivity and accentuated wear of the teeth, in addition to a report of frequently provoked vomiting, in the long term, the condition was suggestive of bulimia nervosa, a diagnosis confirmed after medical evaluation.

Moreover, as regards the association of perimolysis with bulimia, the erosions resulting from it are consequences of regurgitation of the gastric content, initially causing erosion on the palatine surface of maxillary anterior teeth, and subsequent loss of occlusion of the posterior teeth $2,4,12,19$. Fernandes-Neto et al. ${ }^{5}$, added that these conditions of wear are clinically observed only when the vomiting has been stimulated for at least two years, as shown in the case report, in which clinically visible wear presented proximity of the pulp tissue. In more extreme cases, there are reports of the possibility of also affecting the occlusal surface of mandibular posterior teeth and the lingual surface of mandibular anterior teeth 5 .

As other oral characteristics of perimolysis, the presence of thin or fractured tooth edges, slight loss of vertical dimension, tooth hypersensitivity, possibility 
of pulp exposure, alteration in the normal shine of teeth, prominence of amalgam restorations (amalgam isles), chamfered and shortened appearance of teeth, and esthetic compromise were also observed, and all of these factors are also frequently reported in the literature ${ }^{2-3,12}$. However, as regards possible alterations in other oral structures, associated with perimolysis, such as increase in the parotid and salivary glands, xerostomia and irritation of the mucosa ${ }^{3}$, and etiologies related to parafunctional habits and some types of occupational activities ${ }^{20}$, these were not conditions visualized in this clinical case.

There are an increasing number of cases of bulimia and anorexia, although there are no epidemiological data on a population scale in Brazil ${ }^{9-11}$. Moreover, they are difficult to diagnose because they involve the psychological aspect. The dentist may be the first professional to suspect anorexia nervosa and bulimia, due to the signs and symptoms of tooth erosion resulting from a chronically acid oral environment. Therefore it is necessary for the professional to be prepared to perform adequate management of the patient, and to face the difficult task of motivating these patients to seek psychiatric help and dental care, because the majority of patients deny their own disease.

The condition of denial or non acceptance of the disease was extremely evident in the patient in this clinical case, who only after reaching a certain degree of familiarity with the dentist during dental consultations, ended up telling the dentist that she provoked vomiting daily after eating. According to the patient, she had not even reported this condition to the psychiatrist who monitored her for depression. These data associated with the clinical characteristics of the lesion, allowed for the diagnosis of perimolysis, confirming the fact that the dentist is the first professional to come across the characteristics of perimolysis related to psychosomatic disorders ${ }^{9}$.

For this reason, Gaspareto7, Assumpção \& Cabral ${ }^{8}$, Seabra et al. ${ }^{11}$, Camilotti et al. ${ }^{13}$, Nassif et al. ${ }^{21}$ warned dentists with regard to the need for preparation in order to diagnose and refer patients for multidisciplinary treatment, in cases of perimolysis related to intrinsic factors, because many professionals have difficulty in diagnosing and preventing this pathology, due to its etiologies.

To Porto Neto et al. ${ }^{1}$, the option for a certain treatment, in these conditions, demands a careful clinical evaluation and anamnesis, in addition to referrals to other professionals in the area of health care (doctors, psychologists, nutritionists and others). Among the dental treatment options for this pathology, the use of direct resin composite or glass ionomer cement restorations is pointed out. In addition there are indirect restorations such as laminated veneers, inlays, onlays or total crowns, according to the complexity of the case $\mathrm{e}^{2-4,8,10,12-13}$. It is also necessary to perform preventive treatment (fluoride and mouth washes) and provide oral hygiene instructions for the maintenance of the treatment performed, and prevention of diseases, including complete removal of the cause.

According to the options related in the literature ${ }^{9,22-25}$, which emphasizes that in young patients, it is preferable to use conservative restorative treatment by means of adhesive methods, so that there will be no further tooth wear. In this clinical case, in addition to the fact that the patient was young, the degree of wear she presented pointed towards a conservative restorative treatment based on direct restorations with resin composite. Moreover, this allowed the patient to accept having the treatment performed, because she felt very insecure and had difficulty in accepting any type of treatment, particularly more invasive treatments.

In addition to the restorative and preventive dentistry approach, the patient was referred for psychotherapy treatment, because this condition required a multidisciplinary approach.

\section{CONCLUSION}

Based on a review of the literature and the clinical case conducted, it was concluded that: the treatment of dental perimolysis must be performed in a multidisciplinary manner, involving doctors, dentists, psychologists and nutritionists; correct diagnosis is necessary in order to establish a suitable treatment plan; the direct restorative technique performed was shown to be efficient and conservative, restoring the shape, function and esthetics of the teeth and comfort to the patient; Dentists must keep themselves up-to-date with respect to the causes and forms of manifestation of perimolysis and its treatment, including qualification for rehabilitative clinical procedures, as well as for the establishment of the preventive measures necessary for this condition.

\section{Collaborators}

CP DANIEL, JBB CERQUEIRA-LEITE, FB MAGNANI, assisted the patient in the case here reported, and participated in all the stages of writing the article. HA $\mathrm{RICCl}$ participated in all the stages of writing the article and in its submission to this journal. 


\section{REFERENCES}

1. Porto Neto ST, Machado CT, Possabon RT, Carreiro AFP. Erosão dental (perimólise) associada à problemas gástricos e hábitos parafuncionais- uma visão de tratamento multidisciplinar-parte I. J Bras Clin Estet Odontol. 2000;4(21):52-6.

2. Resende VLS, Castilho LS, Faria CVCM, Teixeira GS, Lima ICP, Campos MCBM, et al. Erosão dentária ou perimólise: a importância do trabalho da equipe em saúde. Arq Odontol. 2005;41(2):132-8

3. Pegoraro CN, Sakamoto FFO, Domingues LA. Perimólise etiologia, diagnóstico e prevenção, Rev Assoc Paul Cir Dent. 2000;54(2):156-61

4. Santos RL, Barbosa RPS. Erosão dentária e perimólise: guia para orientação dos cirurgiões-dentistas. Odontol Clin Cientif. 2004;3(2):147-8

5. Fernandes-Neto AJ, Mota AS, Neves FD, Prado MR, Teixeira CJ, Nogueira LAA. Disfunção dentária. Rev Fac Univ Fed Uberlândia. 2006;108-19.

6. Mariotto LA, Delgado RJM. Perimólise: relato de caso. Rev Cienc Odont. 2004;(7):7.

7. Gasparetto R, Nadin MA, Moro AL, Silva SBA. Perimólise: revisão de literatura. Rev Fac Odontol Univ Passo Fundo. 2005;10(1):17-23.

8. Assumpção CL, Cabral MD. Complicações clínicas da anorexia nervosa e bulimia nervosa. Rev Bras Psiquiatr. 2002;24(3):29-33. doi: 10.1590/S1516-44462002000700007

9. Imfeld C, Imfeld T. Transtornos alimentares II, aspectos dentários. Schweiz Monatsschr Zahnmed. 2005;115(12):1163-73.

10. Traebert J, Moreira EAM. Transtornos alimentares de ordem comportamental e seus efeitos sobre a saúde bucal na adolescência. Pesqui Odontol Bras. 2001;15(4):359-63. doi: 10.1590/S1517-74912001000400015

11. Seabra BGM, Ferreira JMS, Seabra FRG. Anorexia nervosa e bulimia nervosa e seus efeitos sobre a saúde bucal. Rev Bras Patol Oral. 2004;3(4):195-8.

12. Silva CEG, Stein O, Dinelli W, Bevilacqua FM. Perimólise dentária: etiologia, diagnóstico e tratamento. Relato de caso. Rev Odont News. 2007;22:8-9

13. Camilotti PP, Venturini AF, Cardoso SA. Perimólise: etiologia, diagnóstico e tratamento - caso clínico. Arq Ciênc Saúde Uniapar. 2003;7:23-5.

14. Cardoso Guedes C, Kalil SB, Mutarelli PS. Estudo das alterações bucais que auxiliam no diagnóstico da bulimia nervosa do tipo purgativo: revisão de literatura. Pediatr Mod. 2007;43(6):303-8.
15. Chehal HK, Pate DH, Cohen DM, Bhattacharyya I. Dental erosion due to excessive wine consumption. Gen Dent. 2009;57(5):519-23.

16. Ligh RQ, Fridgen J, Saxton C. The effect of nutrition and diet on dental structure integrity. J Calif Dent Assoc. 2011;39(4):243-9.

17. Popoff DAV, Santa-Rosa TTA, Paula ACF, Biondi CMF, Domingos MA, Oliveira AS. Bulimia: manifestações bucais e atenção odontológica. RGO - Rev Gaúch Odontol. 2010;58(3):381-5.

18. Ranjitkar S, Kaidonis JA, Smales RJ. Gastroesophageal reflux disease and tooth erosion. Int J Dent. 2012;2012:479850. doi: $10.1155 / 2012 / 479850$

19. Pereira RPA, Negreiros WA, Scarparo MN, Pigozzo MN, Consani RLX, Mesquita MF. Bruxismo e qualidade de vida. Rev Odonto Ciênc. 2006;21(52):185-90.

20. Abrahamsen TC. The worn dentition: pathognomonic patterns of abrasion and erosion. Int Dent J. 2005;55(4 Suppl 1):268-78.

21. Nassif ACS, Begosso MP, Corrêa MSNP. Perimolisis: erosión química del esmalte dental. Rev Ibero-am Odontopediatr Odontol Bebê. 2004;7(36):150-8.

22. Broliato GA, Volcato DB, Reston EG, Kramer PF, Marquezan M, Ruzzarin $F$, et al. Esthetic and functional dental rehabilitation in a patient with gastroesophageal reflux. Quintessence Int. 2008;39(2):131-7.

23. Schmidlin PR, Filli T, Imfeld C, Tepper S, Attin T. Three-year evaluation of posterior vertical bite reconstruction using direct resin composite--a case series. Oper Dent. 2009;34(1):102-8. doi: $10.2341 / 08-11$

24. Reston EG, Closs LQ, Busato AL, Broliato GA, Tessarollo FR. Restoration of occlusal vertical dimension in dental erosion caused by gastroesophageal reflux: case report. Oper Dent. 2010;35(1):125-9. doi: 10.2341/09-110T

25. Messias DCF, Serra MC, Turssi CP. Estratégias para prevenção e controle da erosão dental. RGO - Rev Gaúch Odontol. 2011;59:7-13. 
